\title{
The use of the Lean Method and Failure Mode and Effects Analysis (FMEA) on Product Costing - An Implementation in Automotive Battery Manufacturing
}

\author{
Vega Prasetyo ${ }^{1, a}$, Jani Rahardjo ${ }^{2, b}$ \\ ${ }^{1,2}$ Industrial Engineering Masters Study Program, Petra Christian University, Jl. Siwalankerto 121-131, \\ Surabaya 60236, Indonesia \\ anamich.vega@gmail.com, bjani@petra.ac.id
}

\begin{abstract}
This paper reporst a research that was conducted to utilize lean method and failure mode and effects analysis (FMEA) in product costing, in order to obtain more rational price standard. FMEA as one of the methods to analyze risks is used in this paper as a tool to identify the risks from the waste side which is then adapted into a product costing in order to obtain a more rational product price structure. Utilizing both methods produce a waste priority number with adjustment value of $52.23 \%$ to the existing product cost. This adjustment makes the cost of product higher than before but yields less gap with the highest retail price.
\end{abstract}

Keywords: FMEA, failure mode and effect analysis, lean method, product costing.

\section{Introduction}

Seeing the increasingly rapid business development with the level of competition that is also getting tighter, only companies that are responsive to these conditions can win the competition. Responsiveness includes the ability of companies to see opportunities for improvement (improvement) on all fronts, such as quality improvement, performance improvement, manufacturing cost reduction, all of which lead to increased customer satisfaction and increased customer orders.

Strategic thinking using lean concepts can help companies to identify and eliminate non-value-added resources. Besides that, various issues related to competition, increasing customer expectations, changing requirements and the use of more sophisticated technologies, further spurred producers to minimize, even eliminate, variations that occur in products and processes. If not, then the company must be ready to lose its market share due to customer dissatisfaction.

In the lead-acid automotive battery manufacturer, the most significant use of basic raw materials for prices is lead $(\mathrm{Pb})$. The proportion of raw materials or processes for these materials reaches up to $+60 \%$ of the total costing of the product.

Even small price changes will have a major impact on the price of a product or on a company's profit. Companies can only compete in a way

- Increase productivity, efficiency and effectiveness of work

- Increase the level of quality

- Reducing operational costs

- Reducing the level of waste, in this case is increasing the effectiveness of the use of material leads

Lean thinking is not an analytical method, but applying its operational principles and applications, can drive change in organizational culture, increase efficiency and capabilities and better customer relations. FMEA is a tool to identify and capture potential errors or failures that may occur at each stage of the process, along with the effects it can cause and measure the level or level of severity, occurrence and detection. Some authors have described or discussed Lean, FMEA, or a combination of lean and FMEA. Some authors have also discussed material related to product costing. FMEA methodology is applied to lean production systems to identify waste in a building industry whose products are wood doors and windows made to order [1]. Paciarotti conducted research in the dye industry and modified FMEA from the concept of failure thinking into the concept of thinking defects [2]. Paciarotti still uses three risk parameters in traditional FMEA, but changes his interpretation into the realm of quality. He uses FMEA so that it can be used as a methodology for managers to make quality-related decisions. Sawhney uses the FMEA approach of four critical resources, which are needed to achieve sustainable lean, namely: personnel, equipment, materials, and schedules [3]. In his research, Sawhney and colleagues discovered what they called the RAV or Risk Assessment Value, which is a value for testing the reliability of an existing lean system. Sutrisno uses the concept of thinking FMEA as a tool to manage wastes, and develops RPN into a WPN (waste priority number) by prioritizing waste management [4]. Lopez conducted a costing study on VSM and found what is called VSC (value stream costing) to assess the effectiveness of a VSM [5]. Womack suggests the use of values stream costing (product-based costing) in product design and sales, as well as in the manufacturing process, so that all parties or elements involved in the value stream can see whether the efforts or activities they do have value value-added or not [6]. Costoriented research on FMEA has also been carried out by considering the cost of quality on risk value (RPN) [7].

The current costing structure used has considered various allowances but has not considered a lean perspective (in this case waste that can occur at each stage of the process). Wastes have been considered in costing and calculated as an allowance factor. However, there is no identification of waste measured at each stage of the process. The identification of waste and its effects will be carried out using the FMEA method

\section{Research Methodology}

\subsection{Lean Concept}

Lean production is a further development of the JIT (justin-time) concept that was proclaimed by Toyota in the Toyota Production System (TPS), which aims to reduce "Young" or waste [8]. Young is translated as everything that has no added value, non-value added (NVA). According to Womack and 
Jones, processes in manufacturing appear as a value stream where wastage flows from the beginning to the end of the process [6]. There are 7 forms of waste, namely: transport, inventory, motion, waiting, over-processing, over-production, and defects. All of them have an impact on both performance quality and cost. All these wastes are non-value added (NVA), which customers will not pay [9]. One tool to see the process flow is VSM or value stream mapping [10]. The process map describes the flow of all processes, activities and materials and information through the entire manufacturing process, complete with information about cycle time, downtime, inventory, and so on. VSM is a method that has been accepted and used by many practitioners to improve production systems using lean principles. To obtain sustainable lean, four approaches to four critical resources can be done using the FMEA method: personnel, equipment, materials, and schedules [3].

\subsection{Failure Mode and Effects Analysis (FMEA)}

FMEA is an analytical method used to ensure that all potential problems and risks have been thoroughly identified at the stage of product and process development through an advanced product quality planning - APQP process [11]. FMEA identifies every potential error and its effect and completes it with severity (S), occurrence (O) and detection (D) values. RPN or risk priority number is the risk value that will be the priority target of repairs, and obtained from the results of multiplication $\mathrm{S}, \mathrm{O}$, and $\mathrm{D}$

$$
\mathrm{RPN}=\mathrm{S} \times \mathrm{O} \times \mathrm{D}
$$

Even more important is that FMEA must be done before a problem occurs (before-the-event) not after a problem occurs (after-the-event), because the essence of FMEA is as a risk evaluation tool. FMEA Process (P-FMEA) is a systematic method for analyzing defects in manufacturing processes [12]. FMEA can be used as a methodology for managers to make quality-related decisions [2]. According to Teng and Ho, FMEA is a popular tool for reliability and failure-mode analysis. Therefore, FMEA should be carried out both on the stages of product design and manufacturing [13]. Development or manufacture of FMEA is carried out with a multidisciplinary or cross-functional approach [11]. FMEA is also proven to be adopted to identify and control and reduce wastes [1].

\subsection{Product Costing}

Womack suggests the use of value stream costing (product-based costing) methods on product design and sales, as well as in manufacturing processes, so that every element in the value stream understands whether or not their activities have value-added [6]. In today's business competition, innovation in products and processes holds a very important role. Therefore, the cost management method is expected to help manufacturers to design products and processes at low cost, such as cost reduction and waste elimination [14]. Target costing is an important area, where there are two different approaches in terms of marketing and design, so that it can determine the right design in accordance with the wishes or target prices of the customer. Product costing is a product pricing strategy or method during product development [15]. Cost calculation as one of the tools for pricing, is slowly beginning to lose its strength, because the price of a product is currently very much controlled by the market. Companies cannot provide higher product prices than similar products if they are not accepted by the market [16]. The challenge of the manufacturing industry today is to make products with low cost, good quality and timely delivery [17].

\subsection{Analyze production process flow chart}

The initial step of this research is to analyze the existing production process flow-chart (PPFC). PPFC describes the entire flow of processes and materials from the initial receipt of raw materials to finished products that are ready to be sent to customers. Every process has a process code. Review is conducted with the aim to identify the possibilities of waste that arise at each stage of the process. Identifying waste follows the category of wastes used by Souza and Carpineti [1] as shown in Table 1

Tabel 1. Wastes Category (Souza and Carpinetti, 2014)

\begin{tabular}{ll}
\hline Waste mode & \multicolumn{1}{c}{ Waste mode causes } \\
\hline 1. Over & 1.1. Production excess of demand \\
production & 1.2. Be unsure about non-conformance \\
& 1.3. Large warehouses of finished goods \\
& 1.4. High transportation cost \\
& 1.5. Inaccurate process control plan \\
& 1.6. Anticipation of production \\
\hline 1.7. Poor planning or no order forecast \\
\hline inventory & 2.1. Excess of in-process inventory \\
& 2.2. Difficulty and inefficiency in dealing with \\
& 2.3. Supplier's MOQ \\
& 2.4. Customer's property \\
& 2.5. Discontinued order \\
\hline
\end{tabular}

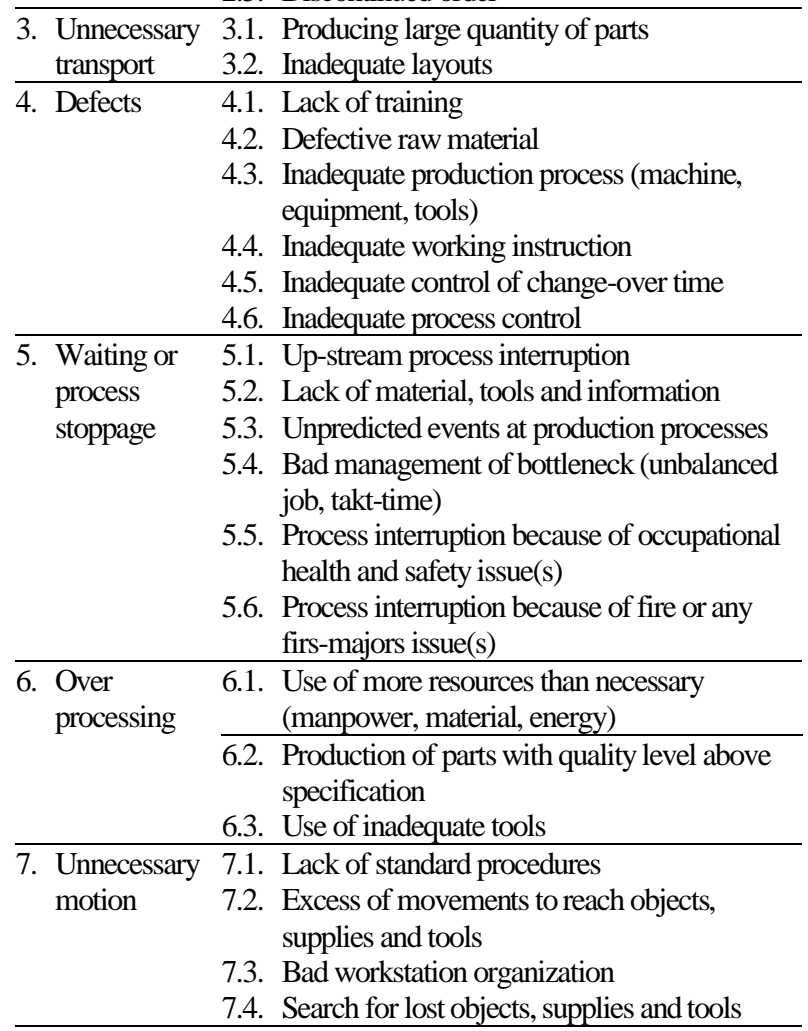




\subsection{Analyze current P-FMEA}

After the type of waste in each process is identified, then the wastes are included in the modified P-FMEA Table 1 above. Next, using the FMEA method the following activities are carried out:

a) Analyzing the causes of waste

b) Give weight to the frequency of events (O), and the detection rate occurs waste (D)

c) Analyzing the effects caused by the waste

d) Give weight to the seriousness or severity (S) of the effect

e) Calculate the value of WPN or Waste Priority Number, with formulas similar to RPN calculations, namely:

$$
\mathrm{WPN}=\mathrm{O} \times \mathrm{S} \times \mathrm{D}
$$

W-FMEA contains information as follows:

\section{Occurrence (O)}

Is the frequency or level of frequency of occurrence of these wastes in certain processes. Adopting the method used by Agung Sutrisno [4], the following Table 2 is used as a reference for setting the occurrence $(\mathrm{O})$ value of waste mode.

Table 2. Occurrence Level for W-FMEA [4]

\begin{tabular}{|c|c|c|}
\hline $\begin{array}{c}\text { Linguistic } \\
\text { Interpretation }\end{array}$ & Time span criteria & Score \\
\hline $\begin{array}{l}\text { Very high probability of } \\
\text { waste variable occurrence }\end{array}$ & $\begin{array}{l}\text { Waste variable is happened } \\
\text { all the time. It is impossuble } \\
\text { to avoid occureence of waste } \\
\text { variable }\end{array}$ & $0.9-1.0$ \\
\hline $\begin{array}{l}\text { High probability of waste } \\
\text { variable occurrence }\end{array}$ & $\begin{array}{l}\text { Waste variable occur every } 1 \\
\text { month. Low possibility to } \\
\text { avoid waste variables }\end{array}$ & $0.7-0.8$ \\
\hline $\begin{array}{l}\text { Medium probability of } \\
\text { waste variable occurrence }\end{array}$ & $\begin{array}{l}\text { Waste variable occur every } \\
\text { 1-3 month. Medium } \\
\text { possibility to avoid waste } \\
\text { variables }\end{array}$ & $0.5-0.6$ \\
\hline $\begin{array}{l}\text { Low probability of waste } \\
\text { variable occurrence }\end{array}$ & $\begin{array}{l}\text { Waste variable occur every } \\
4-6 \text { month. High chance to } \\
\text { get rid of waste variables }\end{array}$ & $0.3-0.4$ \\
\hline $\begin{array}{l}\text { Very lowprobability of } \\
\text { waste variable occurrence }\end{array}$ & $\begin{array}{l}\text { Waste variable may occur in } \\
\text { more than } 1 \text { year. Very high } \\
\text { chance to get rid of waste } \\
\text { variables }\end{array}$ & $0.1-0.2$ \\
\hline
\end{tabular}

\section{Detection (D)}

Is the level of ease or how fast the existing system can detect the occurrence of waste mode above. As is the case for occurrence, the results of research from Agung Sutrisno [4] were also adopted to determine the detection rate of waste mode.

Table 3. Detection Level for W-FMEA [4]

\begin{tabular}{lll}
\hline $\begin{array}{c}\text { Linguistic } \\
\text { Interpretation }\end{array}$ & \multicolumn{1}{c}{ Detection creteria } & Score \\
\hline $\begin{array}{l}\text { Very high probability } \\
\text { undetected variable }\end{array}$ & $\begin{array}{l}\text { Waste variable is almost } \\
\text { undertected. It is impossible } \\
\text { to detect the occurrence of } \\
\text { maintenance waste variable } \\
\text { using current detection tools }\end{array}$ \\
\hline
\end{tabular}

\begin{tabular}{lll}
\hline \multicolumn{1}{c}{$\begin{array}{c}\text { Linguistic } \\
\text { Interpretation }\end{array}$} & \multicolumn{1}{c}{ Detection creteria } & Score \\
$\begin{array}{l}\text { High probability of waste } \\
\text { variable undertected }\end{array}$ & $\begin{array}{l}\text { Medium probability to detect } \\
\text { the occurrence of } \\
\text { maintenance waste using } \\
\text { available detection tool }\end{array}$ & $0.7-0.8$ \\
$\begin{array}{l}\text { Medium probability of } \\
\text { waste variable } \\
\text { undertected }\end{array}$ & $\begin{array}{l}\text { High possibility to detect the } \\
\text { occurrence of waste variable }\end{array}$ & $0.5-0.6$ \\
$\begin{array}{l}\text { Low probability of waste } \\
\text { variable undertected }\end{array}$ & $\begin{array}{l}\text { Very high to detect the } \\
\text { occurrence of maintenance } \\
\text { waste variable }\end{array}$ & $0.3-0.4$ \\
$\begin{array}{l}\text { Very low probability of } \\
\text { waste variable }\end{array}$ & $\begin{array}{l}\text { Waste variable occurrence is } \\
\text { certainly detectable with } \\
\text { confident }\end{array}$ & $0.1-0.2$ \\
\hline
\end{tabular}

\section{Severity (S)}

Is the level of seriousness of the risk of waste. Assessment of the level of severity is as found in Table 4, where even this table adopts the results of research from Agung Sutrisno [4]

Table 4. Severity Level for W-FMEA [4]

\begin{tabular}{|c|c|c|c|c|}
\hline Scale & $\begin{array}{l}\text { Detect ability } \\
\text { of waste sause }\end{array}$ & $\begin{array}{l}\text { Probability of } \\
\text { occurrence of } \\
\text { waste }\end{array}$ & $\begin{array}{l}\text { Rectification } \\
\text { Difficulty }\end{array}$ & $\begin{array}{l}\text { Expected } \\
\text { Cost }\end{array}$ \\
\hline $0.9-1.0$ & $\begin{array}{l}\text { Absolutely } \\
\text { diffecult to } \\
\text { detect the } \\
\text { cause of waste }\end{array}$ & $\begin{array}{l}\text { Certainty on the } \\
\text { probability of } \\
\text { cause occurrence }\end{array}$ & $\begin{array}{l}\text { Impossible to } \\
\text { rectify }\end{array}$ & $\begin{array}{l}\text { Extremely } \\
\text { high }\end{array}$ \\
\hline 0.8-0.9 & $\begin{array}{l}\text { Very difficult } \\
\text { to detect the } \\
\text { cause of } \\
\text { failure }\end{array}$ & $\begin{array}{l}\text { Very high } \\
\text { probability of } \\
\text { cause occurrence }\end{array}$ & Very difficult & Very high \\
\hline $0.6-0.7$ & $\begin{array}{l}\text { Difficukt to } \\
\text { detect the } \\
\text { failure cause }\end{array}$ & High probability & $\begin{array}{l}\text { Medium } \\
\text { difficult }\end{array}$ & Moderate \\
\hline 0.4-0.5 & $\begin{array}{l}\text { Medium } \\
\text { difficult to } \\
\text { detect the } \\
\text { waste cause }\end{array}$ & $\begin{array}{l}\text { Medium } \\
\text { probability of } \\
\text { detection }\end{array}$ & Low difficult & Medium \\
\hline $0.2-0.3$ & $\begin{array}{l}\text { Easy to detect } \\
\text { the waste } \\
\text { cause }\end{array}$ & $\begin{array}{l}\text { Low probability } \\
\text { of detection }\end{array}$ & $\begin{array}{l}\text { Very low } \\
\text { difficult }\end{array}$ & Low \\
\hline 0.1 & $\begin{array}{l}\text { Very easy to } \\
\text { detect the } \\
\text { waste cause }\end{array}$ & $\begin{array}{l}\text { Very low } \\
\text { probability }\end{array}$ & $\begin{array}{l}\text { Extremely low } \\
\text { difficult }\end{array}$ & Very low \\
\hline
\end{tabular}

\subsection{Analyze product costing structure}

The costing structure is divided into several segments:

1) Product specifications

a. Types of products

b. Product combination

2) Costing the lead materials

a. Types of terminals, bushings, connectors, grids, plates

b. Grid and plate volume

c. Types of lead material: pure leads, antimony, calcium

d. Waste or allowance that occurs for each type of material, according to the process

3) Costing non-lead materials

a. Material type: separator, container, electrolyte, packaging, accessories

b. Amount or volume of each material

c. Waste or allowance that occurs for each type of material, according to the process 
4) Costing of burden cost

a. Energy costs: electricity, gas, water

b. Labor costs

c. Maintenance costs (buildings, machinery, vehicles)

d. Cost of interest

\section{Data Analysis and Discussion}

\subsection{Analyze PPFC}

The initial stage of this research is to analyze the production process flow chart (PPFC) with the aim of identifying the possibilities of waste that occur at each stage of the process. Each process will have a unique ID number called process code, as example below:

\begin{tabular}{ll}
\hline Process Code & Process Name \\
\hline PI-02 & Casting Antimony \\
PI-03 & Casting Calcium \\
PI-04 & Sheet Caster \\
PI-05 & Oxide mixing \\
\hline
\end{tabular}

Every process has the possibility to produce waste. In this stage, the possibilities of waste are inventoried for each process by observing and brainstorming with the company's work team. The table below is an example:

\begin{tabular}{|c|c|c|c|c|c|}
\hline $\begin{array}{l}\text { Proces } \\
\text { Code }\end{array}$ & $\begin{array}{l}\text { Process } \\
\text { Name }\end{array}$ & $\begin{array}{l}\text { Waste } \\
\text { Type }\end{array}$ & Waste & $\begin{array}{c}\text { Waste } \\
\text { ID }\end{array}$ & Waste Mode \\
\hline PI-02 & $\begin{array}{l}\text { Casting } \\
\text { Antimony }\end{array}$ & 1 & $\begin{array}{l}\text { Over } \\
\text { Production }\end{array}$ & 1.1 & $\begin{array}{l}\text { Production excess of } \\
\text { demand }\end{array}$ \\
\hline PI-02 & $\begin{array}{l}\text { Casting } \\
\text { Antimony }\end{array}$ & 1 & $\begin{array}{l}\text { Over } \\
\text { Production }\end{array}$ & 1.6 & $\begin{array}{l}\text { Anticipation of } \\
\text { production }\end{array}$ \\
\hline PI-02 & $\begin{array}{l}\text { Casting } \\
\text { Antimony }\end{array}$ & 1 & $\begin{array}{l}\text { Over } \\
\text { Production }\end{array}$ & 1.7 & $\begin{array}{l}\text { Poor planning or no } \\
\text { order forecast }\end{array}$ \\
\hline PI-03 & $\begin{array}{l}\text { Casting } \\
\text { Calcium }\end{array}$ & 1 & $\begin{array}{l}\text { Over } \\
\text { Production }\end{array}$ & 1.1 & $\begin{array}{l}\text { Production excess of } \\
\text { demand }\end{array}$ \\
\hline PI-03 & $\begin{array}{l}\text { Casting } \\
\text { Calcium }\end{array}$ & 1 & $\begin{array}{l}\text { Over } \\
\text { Production }\end{array}$ & 1.6 & $\begin{array}{l}\text { Anticipation of } \\
\text { production }\end{array}$ \\
\hline PI-03 & $\begin{array}{l}\text { Casting } \\
\text { Calcium }\end{array}$ & 1 & $\begin{array}{l}\text { Over } \\
\text { Production }\end{array}$ & 1.7 & $\begin{array}{l}\text { Poor planning or no } \\
\text { order forecast }\end{array}$ \\
\hline PI-03 & $\begin{array}{l}\text { Casting } \\
\text { Calcium }\end{array}$ & 2 & $\begin{array}{l}\text { Over } \\
\text { Inventory }\end{array}$ & 2.1 & $\begin{array}{l}\text { Excess of in-process } \\
\text { inventory }\end{array}$ \\
\hline
\end{tabular}

\subsection{Analyze P-FMEA}

\section{Analyze potential caused}

The identified waste will then be analyzed for the causes. The analysis is carried out by brainstorming and observation in the field and getting a list as follows:

\begin{tabular}{ll}
\hline Cause ID & \multicolumn{1}{c}{ Cause } \\
\hline 1.1. & Anticipation of product defects \\
1.6. & Anticipation of sudden (unpredicted) orders \\
1.7.a & $\begin{array}{l}\text { Improper production planning because there is no } \\
\text { forecast order }\end{array}$ \\
1.7.b & $\begin{array}{l}\text { The absence of a clear production plan } \\
\text { 2.1.a }\end{array}$ \\
$\begin{array}{l}\text { Grid stock cannot be processed because there is no } \\
\text { plate requirement }\end{array}$ \\
2.1.b & $\begin{array}{l}\text { The grid stock cannot be processed because it is } \\
\text { still in the aging stage }\end{array}$ \\
\hline
\end{tabular}

\section{Determination of level occurrence and detection}

Adopting the criteria for granting the occurrence and detection level of Agung Sutrisno [4], here is a table of criteria for occurrence and detection that has been adjusted to the conditions of the company and used for weighting in WFMEA:

Tabel 5. Occurrence Level

\begin{tabular}{cll}
\hline \multicolumn{1}{c}{ Level } & \multicolumn{1}{c}{ Kriteria } & \multicolumn{1}{c}{ Tingkat Kejadian } \\
\hline $0.9-1.0$ & $\begin{array}{l}\text { Sangat Tinggi } \\
\text { Very High }\end{array}$ & $\begin{array}{l}\text { Kemungkinan kejadian waste sangat } \\
\text { tinggi }\end{array}$ \\
$0.7-0.8$ & $\begin{array}{l}\text { Tinggi } \\
\text { High }\end{array}$ & Kemungkinan kejadian waste tinggi \\
$0.5-0.6$ & $\begin{array}{l}\text { Biasa } \\
\text { Medium }\end{array}$ & $\begin{array}{l}\text { Kemungkinan kejadian waste dalam } \\
\text { batas normal }\end{array}$ \\
$0.3-0.4$ & $\begin{array}{l}\text { Rendah } \\
\text { Low }\end{array}$ & Kemungkinan kejadian waste rendah \\
$0.1-0.2$ & $\begin{array}{l}\text { Sangat Rendah } \\
\text { Very Low }\end{array}$ & $\begin{array}{l}\text { Sangat rendah atau bahkan tidak } \\
\text { mungkin terjadi }\end{array}$ \\
\hline
\end{tabular}

Tabel 6. Detection Level

\begin{tabular}{cll}
\hline Level & \multicolumn{1}{c}{ Kriteria } & \multicolumn{1}{c}{ Tingkat Kejadian } \\
\hline $0.9-1.0$ & $\begin{array}{l}\text { Sangat Tinggi } \\
\text { Very High }\end{array}$ & $\begin{array}{l}\text { Sangat besar kemungkinan kejadian } \\
\text { waste tidak dapat terdeteksi } \\
\text { Besar kemungkinan kejadian waste }\end{array}$ \\
$0.7-0.8$ & $\begin{array}{l}\text { Tinggi } \\
\text { High }\end{array}$ & $\begin{array}{l}\text { tidak dapat terdeteksi } \\
\text { Kejadian waste bisa saja tidak }\end{array}$ \\
$0.5-0.6$ & $\begin{array}{l}\text { Biasa } \\
\text { Medium }\end{array}$ & $\begin{array}{l}\text { Kerdeteksi } \\
\text { teri }\end{array}$ \\
0.4 & $\begin{array}{l}\text { Rendah } \\
\text { Low }\end{array}$ & $\begin{array}{l}\text { Rendah kemungkinan kejadian waste } \\
\text { tidak terdeteksi }\end{array}$ \\
$0.1-0.2$ & $\begin{array}{l}\text { Sangat Rendah } \\
\text { Kejadian waste dengan mudah } \\
\text { Very Low }\end{array}$ & terdeteksi \\
\hline
\end{tabular}

\section{Effects Analysis}

The following are the identified effects that arise as a result of the waste that occurs in accordance with the causes, as an example below:

\begin{tabular}{cl}
\hline Cause ID & \multicolumn{1}{c}{ Effects } \\
\hline 1.1. & $\begin{array}{l}\text { If defective rate is below allowance quantity, } \\
\text { then stock of grids will be increase }\end{array}$ \\
2.1. & Over stock of small parts casting \\
4.5. & A lot of consumption of lead \\
4.6. & Paltes have to scrap \\
\hline
\end{tabular}

Determine the severity level

Table 7. Severity Level

\begin{tabular}{|c|c|c|}
\hline Level & $\begin{array}{c}\text { Kriteria: } \\
\text { Efek terhadap cost }\end{array}$ & $\begin{array}{c}\text { Kriteria: } \\
\text { Efek dari faktor penyebab }\end{array}$ \\
\hline $0.9-1.0$ & $\begin{array}{l}\text { Sangat signifikan } \\
\text { Very significant }\end{array}$ & $\begin{array}{l}\text { Hampir tidak mungkin untuk } \\
\text { medeteksi penyebab dari waste }\end{array}$ \\
\hline $0.8-0.9$ & $\begin{array}{l}\text { Signifikan } \\
\text { Significant }\end{array}$ & $\begin{array}{l}\text { Sangat sulit untuk medeteksi } \\
\text { penyebab dari waste }\end{array}$ \\
\hline $0.6-0.7$ & Moderate & $\begin{array}{l}\text { Sulit untuk mendeteksi penyebab } \\
\text { waste }\end{array}$ \\
\hline $0.4-0.5$ & $\begin{array}{l}\text { Menengah } \\
\text { Medium }\end{array}$ & $\begin{array}{l}\text { Cukup sulit untuk mendeteksi } \\
\text { penyebab waste }\end{array}$ \\
\hline $0.2-0.3$ & $\begin{array}{l}\text { Rendah } \\
\text { Low }\end{array}$ & $\begin{array}{l}\text { Mudah untuk mendeteksi penyebab } \\
\text { waste }\end{array}$ \\
\hline 0.1 & $\begin{array}{l}\text { Sangat Rendah } \\
\text { Very Low }\end{array}$ & $\begin{array}{l}\text { Sangat mudah untuk mendeteksi } \\
\text { penyebab waste }\end{array}$ \\
\hline
\end{tabular}


Calculate the waste priority number (WPN)

If all the value WPN of each potential cause been collected, we will get the table of WPN for each cause as below (example):

Table 8. The results of the calculation of WPN values for each potential cause

\begin{tabular}{clc}
\hline $\begin{array}{c}\text { Cause } \\
\text { ID }\end{array}$ & \multicolumn{1}{c}{ Cause } & $\begin{array}{c}\text { Total } \\
\text { WPN }\end{array}$ \\
\hline 1.1. & Anticipation of product defect & 0.69 \\
1.6. & Anticipation of sudden order & 0.63 \\
1.7.a & Improper production planning & 1.15 \\
1.7.b & Unclear planning & 0.22 \\
2.1.a & Stock grid not ready for production & 0.43 \\
2.3. & MOQ from supplier & 0.64 \\
2.5.a & Design change of grid & 0.60 \\
4.2.b. & Increase volume of dross & 0.42 \\
4.3.a & Inconsisten spraying process & 0.38 \\
5.3. & Change production priority & 1.96 \\
5.6. & Power shutdown & 3.06 \\
etc & & \\
\hline
\end{tabular}

Calculate the priority number of potential cause (Cause Priority Number)

Cause priority number $(\mathrm{CPN})$ is a value that shows the priority of the causes. The $\mathrm{CPN}$ value is calculated by the following formula;

$$
\mathrm{CPN}=\sum_{i=1}^{n} W P N C i x \sum_{i=1}^{n} \text { Effects } C i
$$

Where:

$\begin{array}{ll}\text { CPN } & \text { Cause priority number } \\ \text { WPNCi } & \text { The number of WPN values for each cause of the } \\ & \text { effect caused }\end{array}$

Effects $\mathrm{Ci}$ : The number of effects caused by a particular cause

The result of CPN calculation is shown below:

Table 9. Calculation result of CPN

\begin{tabular}{|c|c|c|c|c|}
\hline $\begin{array}{c}\text { Cause } \\
\text { ID }\end{array}$ & Cause & $\begin{array}{c}\Sigma \\
\text { Effects }\end{array}$ & $\begin{array}{c}\Sigma \\
\text { WPN }\end{array}$ & CPN \\
\hline 1.1. & $\begin{array}{l}\text { Anticipation of product } \\
\text { defect }\end{array}$ & 1 & 0.690 & 0.690 \\
\hline 1.6. & $\begin{array}{l}\text { Anticipation of sudden } \\
\text { order }\end{array}$ & 1 & 0.630 & 0.630 \\
\hline 1.7.a & $\begin{array}{l}\text { Improper production } \\
\text { planning }\end{array}$ & 2 & 1.152 & 2.304 \\
\hline 1.7.b & Unclear planning & 3 & 0.216 & 0.648 \\
\hline 2.1.a & $\begin{array}{l}\text { Stock grid not ready for } \\
\text { production }\end{array}$ & 1 & 0.432 & 0.432 \\
\hline 2.3 . & MOQ from supplier & 4 & 0.640 & 2.560 \\
\hline 2.5.a & Design change of grid & 1 & 0.600 & 0.600 \\
\hline 4.2.b. & $\begin{array}{l}\text { Increase volume of } \\
\text { dross }\end{array}$ & 1 & 0.420 & 0.420 \\
\hline 4.3.a & $\begin{array}{l}\text { Inconsisten spraying } \\
\text { process }\end{array}$ & 1 & 0.375 & 0.375 \\
\hline 5.3. & $\begin{array}{l}\text { Change production } \\
\text { priority }\end{array}$ & 5 & 1.959 & 9.795 \\
\hline $\begin{array}{l}5.6 . \\
\text { etc }\end{array}$ & Power shutdown & 5 & 3.060 & 15.300 \\
\hline
\end{tabular}

\section{Determine critical value of causes (CVc)}

Critical value of causes (CVC) is calculated to determine the critical severity of the causative factors

$$
\begin{aligned}
& \mathrm{CV}_{\mathrm{C}}=\frac{\sum_{i=1}^{n} \text { WPN }}{\text { Total Effects }} \\
& \mathrm{CV}_{\mathrm{C}}=\frac{15.19}{65}=\mathbf{0 . 2 3 4}
\end{aligned}
$$

The causal factor for which the CPN value is greater than the CVC value (in this case is 0.234 ), is categorized as high

\begin{tabular}{|c|c|c|c|c|}
\hline $\begin{array}{l}\text { Cause } \\
\text { ID }\end{array}$ & $\begin{array}{c}\Sigma \\
\text { Effects }\end{array}$ & $\begin{array}{c}\Sigma \\
\text { WPN }\end{array}$ & CPN & Severity \\
\hline 5.6. & 5 & 3.060 & 15.300 & High \\
\hline 5.3. & 5 & 1.959 & 9.795 & High \\
\hline 2.3 . & 4 & 0.640 & 2.560 & High \\
\hline 1.7.a & 2 & 1.152 & 2.304 & High \\
\hline 1.1. & 1 & 0.690 & 0.690 & High \\
\hline 1.7.b & 3 & 0.216 & 0.648 & High \\
\hline 1.6. & 1 & 0.630 & 0.630 & High \\
\hline 2.5.a & 1 & 0.600 & 0.600 & High \\
\hline 2.2 . & 1 & 0.480 & 0.480 & High \\
\hline 2.1.a & 1 & 0.432 & 0.432 & High \\
\hline 4.2.b. & 1 & 0.420 & 0.420 & High \\
\hline 4.3.g & 2 & 0.198 & 0.396 & High \\
\hline 4.3.a & 1 & 0.375 & 0.375 & High \\
\hline 4.5 . & 2 & 0.162 & 0.324 & High \\
\hline 4.4. & 1 & 0.252 & 0.252 & High \\
\hline 2.1.b & 1 & 0.240 & 0.240 & High \\
\hline 5.2.a. & 1 & 0.240 & 0.240 & High \\
\hline 5.2.b. & 1 & 0.240 & 0.240 & High \\
\hline 4.2.c & 1 & 0.228 & 0.228 & Fair \\
\hline 2.1.c & 1 & 0.216 & 0.216 & Fair \\
\hline 2.1.h & 1 & 0.216 & 0.216 & Fair \\
\hline 4.6. & 1 & 0.210 & 0.210 & Fair \\
\hline 5.4. & 1 & 0.200 & 0.200 & Fair \\
\hline 4.2.a & 1 & 0.180 & 0.180 & Fair \\
\hline 6.1.b & 1 & 0.175 & 0.175 & Fair \\
\hline 6.1.a & 1 & 0.162 & 0.162 & Fair \\
\hline 6.1.d & 1 & 0.144 & 0.144 & Fair \\
\hline 5.2.d & 1 & 0.140 & 0.140 & Fair \\
\hline 4.3.i & 1 & 0.126 & 0.126 & Fair \\
\hline 2.1.d & 1 & 0.120 & 0.120 & Fair \\
\hline 2.1.i & 1 & 0.120 & 0.120 & Fair \\
\hline 2.1.e & 1 & 0.100 & 0.100 & Fair \\
\hline 5.2.f & 1 & 0.096 & 0.096 & Fair \\
\hline 2.1.g & 1 & 0.096 & 0.096 & Fair \\
\hline 2.5.b & 1 & 0.096 & 0.096 & Fair \\
\hline 2.5.c & 1 & 0.084 & 0.084 & Fair \\
\hline 4.3.d & 1 & 0.063 & 0.063 & Fair \\
\hline 4.3.f & 1 & 0.063 & 0.063 & Fair \\
\hline 4.3.h & 1 & 0.063 & 0.063 & Fair \\
\hline 4.3.c & 1 & 0.054 & 0.054 & Fair \\
\hline 5.2.e & 1 & 0.048 & 0.048 & Fair \\
\hline 4.3.e & 1 & 0.045 & 0.045 & Fair \\
\hline 6.1.c & 1 & 0.042 & 0.042 & Fair \\
\hline 4.3.b & 1 & 0.027 & 0.027 & Fair \\
\hline 2.1.f & 1 & 0.020 & 0.020 & Fair \\
\hline 5.2.c & 1 & 0.020 & 0.020 & Fair \\
\hline 6.1.e & 1 & 0.020 & 0.020 & Fair \\
\hline 5.1. & 1 & 0.018 & 0.018 & Fair \\
\hline \multirow[t]{3}{*}{ 4.2.d } & 1 & 0.012 & 0.012 & Fair \\
\hline & 65 & 15.19 & & \\
\hline & $\mathrm{CV}_{\mathrm{C}}$ & 0.234 & & \\
\hline
\end{tabular}
risks.

Table 10. Severity value of each potential cause 
It was found that there were 18 causative factors that have a high level of seriousness towards waste and of course the cost. From the 18 causative factors above, we can see the impact that has been made on the process as follows:

Table 11. Impact of causal factors on the process

\begin{tabular}{|c|c|c|}
\hline $\begin{array}{c}\text { Cause } \\
\text { ID }\end{array}$ & Process Name & $\begin{array}{c}\Sigma \\
\text { WPN }\end{array}$ \\
\hline \multirow{3}{*}{1.1.} & Casting Antimony & 0.210 \\
\hline & Casting Calcium & 0.240 \\
\hline & Sheet Caster & 0.240 \\
\hline \multirow[t]{3}{*}{1.6.} & Casting Antimony & 0.210 \\
\hline & Casting Calcium & 0.210 \\
\hline & Sheet Caster & 0.210 \\
\hline \multirow[t]{4}{*}{ 1.7.a } & Casting Antimony & 0.288 \\
\hline & Casting Calcium & 0.288 \\
\hline & Sheet Caster & 0.288 \\
\hline & Expander & 0.288 \\
\hline \multirow[t]{4}{*}{ 1.7.b } & COS (Cast on Strap) & 0.054 \\
\hline & Manual Burning & 0.054 \\
\hline & Welding & 0.054 \\
\hline & Boxing & 0.054 \\
\hline \multirow[t]{2}{*}{ 2.1.a } & Casting Antimony & 0.216 \\
\hline & Casting Calcium & 0.216 \\
\hline \multirow[t]{2}{*}{ 2.1.b } & Casting Antimony & 0.120 \\
\hline & Casting Calcium & 0.120 \\
\hline \multirow[t]{4}{*}{2.2 . } & Casting Antimony & 0.120 \\
\hline & Casting Calcium & 0.120 \\
\hline & Expander & 0.120 \\
\hline & Sheet Caster & 0.120 \\
\hline \multirow[t]{5}{*}{2.3 . } & Storage Container dari Supplier & 0.120 \\
\hline & Storage Cover / Second Cover dari Supplier & 0.120 \\
\hline & Storage Karton Box & 0.180 \\
\hline & Storage Label, Sticker, Brosur, dan Warranty Card & 0.120 \\
\hline & Storage Separator & 0.100 \\
\hline \multirow[t]{4}{*}{ 2.5.a } & Casting Antimony & 0.150 \\
\hline & Casting Calcium & 0.150 \\
\hline & Expander & 0.150 \\
\hline & Sheet Caster & 0.150 \\
\hline \multirow{3}{*}{ 4.2.b. } & Casting Antimony & 0.140 \\
\hline & Casting Calcium & 0.140 \\
\hline & Sheet Caster & 0.140 \\
\hline \multirow{3}{*}{ 4.3.a } & Casting Antimony & 0.125 \\
\hline & Casting Calcium & 0.125 \\
\hline & Sheet Caster & 0.125 \\
\hline \multirow[t]{3}{*}{ 4.3.g } & Hole Punch & 0.072 \\
\hline & 2nd Heat Sealing & 0.063 \\
\hline & Heat Sealing & 0.063 \\
\hline \multirow[t]{4}{*}{4.4.} & Pembuatan Screen & 0.036 \\
\hline & Printing Container & 0.072 \\
\hline & Printing Cover & 0.072 \\
\hline & Printing Karton & 0.072 \\
\hline \multirow[t]{3}{*}{4.5 . } & Casting Antimony & 0.054 \\
\hline & Casting Calcium & 0.054 \\
\hline & Sheet Caster & 0.054 \\
\hline \multirow[t]{4}{*}{ 5.2.a. } & Casting Antimony & 0.060 \\
\hline & Casting Calcium & 0.060 \\
\hline & Pembuatan Tepung Oxide & 0.060 \\
\hline & Sheet Caster & 0.060 \\
\hline \multirow[t]{4}{*}{ 5.2.b. } & Casting Antimony & 0.060 \\
\hline & Casting Calcium & 0.060 \\
\hline & Pembuatan Tepung Oxide & 0.060 \\
\hline & Sheet Caster & 0.060 \\
\hline \multirow[t]{3}{*}{5.3.} & COS (Cast on Strap) & 0.054 \\
\hline & Manual Burning & 0.054 \\
\hline & Welding & 0.054 \\
\hline
\end{tabular}

\begin{tabular}{|c|c|c|}
\hline $\begin{array}{c}\text { Cause } \\
\text { ID }\end{array}$ & Process Name & $\begin{array}{c}\Sigma \\
\text { WPN }\end{array}$ \\
\hline \multirow{25}{*}{5.6.} & Boxing & 0.054 \\
\hline & Printing Container & 0.126 \\
\hline & Printing Cover & 0.126 \\
\hline & Printing Karton & 0.126 \\
\hline & Casting Antimony & 0.210 \\
\hline & Casting Calcium & 0.210 \\
\hline & Charging & 0.210 \\
\hline & Drying Oven & 0.210 \\
\hline & Expander & 0.105 \\
\hline & Formation & 0.210 \\
\hline & Sheet Caster & 0.210 \\
\hline & Curring & 0.240 \\
\hline & Formation & 0.240 \\
\hline & Drying Oven & 0.240 \\
\hline & Pembuatan Tepung Oxide & 0.280 \\
\hline & Casting Antimony & 0.245 \\
\hline & Casting Calcium & 0.245 \\
\hline & Charging & 0.180 \\
\hline & Curring & 0.180 \\
\hline & Drying Oven & 0.180 \\
\hline & Formation & 0.180 \\
\hline & Hot Chamber & 0.180 \\
\hline & Pembuatan Tepung Oxide & 0.245 \\
\hline & Sheet Caster & 0.245 \\
\hline & Steaming Chamber & 0.180 \\
\hline
\end{tabular}

\section{Analyze product costing}

By making WPN stratification at 18 processes that are high risk on the effects of waste, the table obtained the additional cost allowance table as follows:

Table 12. Additional cost allowance

\begin{tabular}{lcc}
\hline \multicolumn{1}{c}{ Proces } & $\boldsymbol{\Sigma}$ WPN & Cost allowance \\
\hline Casting Calcium & 2.238 & 0.147 \\
Casting Antimony & 2.208 & 0.145 \\
Sheet Caster & 1.902 & 0.125 \\
Expander & 0.663 & 0.044 \\
Pembuatan Tepung Oxide & 0.645 & 0.042 \\
Formation & 0.630 & 0.041 \\
Drying Oven & 0.630 & 0.041 \\
Curring & 0.420 & 0.028 \\
Charging & 0.390 & 0.026 \\
Printing Container & 0.198 & 0.013 \\
Printing Cover & 0.198 & 0.013 \\
Printing Karton & 0.198 & 0.013 \\
Hot Chamber & 0.180 & 0.012 \\
Steaming Chamber & 0.180 & 0.012 \\
Storage Karton Box & 0.180 & 0.012 \\
Storage Container dari Supplier & 0.120 & 0.008 \\
Storage Cover / Second Cover dari & 0.120 & 0.008 \\
Supplier & & \\
Storage Label, Sticker, Brosur, dan & 0.120 & 0.008 \\
Warranty Card & & \\
COS (Cast on Strap) & 0.108 & 0.007 \\
Manual Burning & 0.108 & 0.007 \\
Boxing & 0.108 & 0.007 \\
Welding & 0.108 & 0.007 \\
Storage Separator & 0.100 & 0.007 \\
Hole Punch & 0.072 & 0.005 \\
Heat Sealing & 0.063 & 0.004 \\
2nd Heat Sealing & 0.063 & 0.004 \\
Screen Printing Preparation & 0.036 & 0.002 \\
\hline & & $\mathbf{0 . 7 8 8}$ \\
\hline & & \\
\hline & &
\end{tabular}




\section{Modify product costing}

Based on Table 12. above, it is found that there is a cost adjustment for waste risk of $\mathbf{0 . 7 9}$. Thus, the product pricing determination formulation will be as follows

Table 13. Comparison of old and new costing

\begin{tabular}{lcc}
\hline \multirow{2}{*}{ Pricing elements } & \multicolumn{2}{c}{ Battery Type : Nxx } \\
\cline { 2 - 3 } & BEFORE & AFTER \\
\hline Battery Weight (Kg./Pc) & 9.03 & 9.03 \\
LME Price ( USD / MT) & 2,225 & 2,225 \\
Premium ( USD / MT ) & 75 & 75 \\
LME + Premium ( USD / MT ) & 2,300 & 2,300 \\
Dross ( \% ) & $3.00 \%$ & $3.00 \%$ \\
Nett Cost of Lead ( USD / MT ) & 2,369 & 2,369 \\
Exchange rate ( IDR/USD ) & 13,400 & 13,400 \\
Cost of lead ( IDR / Kg ) & 31,745 & 31,745 \\
Unit Price ( IDR / Pc ) & 286,764 & 286,764 \\
\hline \multicolumn{1}{c}{ Manufacturing Cost } & 0.30 & 0.30 \\
\hline \multicolumn{1}{c}{ Additional allowance } & $\mathbf{0 . 7 9}$ \\
\hline \multicolumn{1}{c}{ New Manufacturing Cost } & $\mathbf{0 . 3 0}$ & $\mathbf{1 . 0 9}$ \\
\hline (A) HPP ( IDR / Pc ) & 372,794 & 599,071 \\
(B) HET Jan-18 & 806,000 & 806,000 \\
Difference (B) - (A) & 433,206 & 206,929 \\
\multicolumn{2}{c}{ Adjustment } & $\mathbf{- 5 2 . 2 3 \%}$ \\
\hline
\end{tabular}

From the calculation data above, the gap between the highest retail price in the market and the price of the product becomes smaller. Thus, the company's policy to provide price discounts to distributors must also be tightened, so that the company will avoid losses. There is additional allowance of 0.79 added to the cost structure that represent cost of potential waste at the production line that not recognized yet considered. This is a hidden cost that makes company looks like gain a profit but is vice-versa. The more quantity sold; the more loss will be obtained. The gap between product cost with highest retail product is reduced by $52.23 \%$ meaning that company must realize and adjut the profit margin. At the start, the proft margin will be less than expectation but after the improvement taken, company will gain more profit. The priority of improvement should be taken to the highest WPN of the 18 causative factors.

\section{Conclusion and further research}

The failure mode and effects analysis (FMEA) method can be used to rationalize product prices by using them together with lean methodologies, by identifying waste that occurs at each stage of the process. Requires commitment and carefulness and openness of the manufacturing team to be able to see and identify existing waste. Constraints that arise are mostly a "habit" factor, so seeing something abnormal as something normal. FMEA is proven to be used as a tool to improve manufacturing systems, not only in terms of product quality but also for matters relating to lean and even the cost of producing a product. Further research can be focusing on improving 18 causative factors by utilizing Six Sigma methodology.

\section{References}

1. Souza, R.V.B. De and Carpinetti, L.C.R. (2014), “A FMEA-based approach to prioritize waste reduction in lean implementation", International Journal of Quality \& Reliability Management, Vol. 31 No. 4, pp. 346-366.

2. Paciarotti, C., Mazzuto, G. and D'Ettorre, D. (2014), "A revised FMEA application to the quality control management", International Journal of Quality \& Reliability Management, Vol. 31 No. 7, pp. 788-810.

3. Sawhney, R., Subburaman, K., Sonntag, C., Rao, P.R.V. and Capizzi, C. (2010), "A modified FMEA approach to enhance reliability of lean systems", International Journal of Quality \& Reliability Management, Vol. 27, pp. 832-855.

4. Sutrisno, A., Gunawan, I. and Tangkuman, S. (2015), "Modified Failure Mode and Effect Analysis (FMEA) Model for Accessing the Risk of Maintenance Waste", Procedia Manufacturing, Elsevier B.V., Vol. 4 No. Iess, pp. 23-29.

5. Ruiz-de-Arbulo Lopez, P., Fortuny-Santos, J. and Cuatrecasa-Arbós, L. (2013), "Lean manufacturing: costing the value stream", Industrial Management \& Data Systems, Vol. 113 No. 5, pp. 647-668.

6. Womack, J.P. and Jones, D.T. (2003), "Lean Thinking", Lean Thinking, pp. 50-66.

7. von Ahsen, A. (2008), "Cost-oriented failure mode and effects analysis", International Journal of Quality \& Reliability Management, Emerald Group Publishing Limited, Vol. 25 No. 5, pp. 466-476.

8. Womack, J.P., Jones, D.T. and Roos, D. (1990), “The Machine that Changed the World: The Story of Lean Production", World, pp. 1-11.

9. Cherrafi, A., Elfezazi, S., Chiarini, A., Mokhlis, A. and Benhida, K. (2016), "The integration of lean manufacturing, Six Sigma and sustainability: A literature review and future research directions for developing a specific model", Journal of Cleaner Production, Vol. 139, pp. 828-846.

10. Rother, M. and Shook, J. (2003), "Learning to See: Value Stream Mapping to Add Value and Eliminate Muda (Lean Enterprise Institute)", Lean Enterprise Institute Brookline.

11. AIAG. (2008), Potential Failure Mode and (FMEA) Reference Manual Fourth Edition, Design, Automotive Industry Action Group (AIAG), available at: www.aiag.org.

12. Haefner, B., Kraemer, A., Stauss, T. and Lanza, G. (2014), "Quality value stream mapping", Procedia CIRP, Elsevier B.V., Vol. 17, pp. 254-259.

13. Sheng-Hsien (Gary) Teng and Ho, S.-Y. (Michael). (1996), "Failure mode and effects analys is An integrated approach for product", International Journal of Quality \& Reliability Management, Vol. 13 No. 5, pp. 8-26.

14. Gagne, M.L. and Discenza, R. (1995), "Target costing.pdf', Journal of Business \& Industrial Marketing, Vol. 10 No. 1, pp. 16-22. 
15. Kee, R. and Matherly, M. (2014), "Target Costing in the Presence of Product and Production Interdependencies.pdf'.

16. Kádárová, J., Teplická, K., Durkáčová, M. and Vida, M. (2015), "Target Costing Calculation and Economic Gain for Companies", Procedia Economics and Finance.
17. Rohani, J.M. and Zahraee, S.M. (2015), "Production Line Analysis via Value Stream Mapping: A Lean Manufacturing Process of Color Industry", Procedia Manufacturing, Elsevier B.V., Vol. 2 No. February, pp. 6-10. 